\title{
Use of Tranexamic acid is a cost effective method in preventing blood loss during and after total knee replacement
}

\author{
Yasir J Sepah', Masood Umer ${ }^{2 *}$, Tashfeen Ahmad ${ }^{3}$, Faria Nasim ${ }^{1}$, Muhammad Umer Chaudhry ${ }^{1}$ and \\ Muhammad Umar ${ }^{4}$
}

\begin{abstract}
Background \& Purpose: Allogenic blood transfusion in elective orthopaedic surgery is best avoided owing to its associated risks. Total knee replacement often requires blood transfusion, more so when bilateral surgery is performed. Many strategies are currently being employed to reduce the amount of peri-operative allogenic transfusions. Anti-fibrinolytic compounds such as aminocaproic acid and tranexamic acid have been used systemically in perioperative settings with promising results. This study aimed to evaluate the effectiveness of tranexamic acid in reducing allogenic blood transfusion in total knee replacement surgery.
\end{abstract}

Methodology: This was a retrospective cohort study conducted on patients undergoing total knee replacement during the time period November 2005 to November 2008. Study population was 99 patients, of which 70 underwent unilateral and 29 bilateral knee replacement. Forty-seven patients with 62 (49.5\%) knees (group-l) had received tranexamic acid (by surgeon preference) while the remaining fifty-two patients with 66 (51.5\%) knees (group-II) had did not received any tranexamic acid either pre- or post-operatively.

Results: The mean drop in the post-operative haemoglobin concentration in Group-II for unilateral and bilateral cases was $1.79 \mathrm{gm} / \mathrm{dl}$ and $2.21 \mathrm{gm} / \mathrm{dl}$, with a mean post-operative drainage of $1828 \mathrm{ml}$ (unilateral) and $2695 \mathrm{ml}$ (bilateral). In comparison, the mean drop in the post-op haemoglobin in Group-l was $1.49 \mathrm{gm} / \mathrm{dl}$ (unilateral) and $1.94 \mathrm{gm} / \mathrm{dl}$ (bilateral), with a mean drainage of $826 \mathrm{ml}$ (unilateral) and $1288 \mathrm{ml}$ (bilateral) ( $\mathrm{p}$-value < 0.001).

Interpretation: Tranexamic acid is effective in reducing post-operative drainage and requirement of blood transfusion after knee replacement.

\section{Introduction}

Total knee replacement is a frequently done procedure in modern day practice of any Orthopedics unit. Limiting blood loss both postoperatively and intra-operatively presents a challenge to the surgeon. Postoperatively, blood continues to ooze from the cut ends of bone, the open intra-medullary canal and the raw, dissected soft tissues. This can amount to significant bleeding with figures ranging from $600-1500 \mathrm{ml}$ [1-7]. As this procedure is performed under tourniquet control, there is an associated increase in localized fibrinolysis, which

\footnotetext{
* Correspondence: masood.umer@aku.edu

${ }^{2}$ Associate Professor Department of Surgery (Orthopedics) Aga Khan

University Hospital, Karachi-74800, Pakistan

Full list of author information is available at the end of the article
}

contributes to two events. Firstly, it decreases the risk of venous thromboembolism and secondly it may aggravate post-operative haemorrhage [8-10]. The problem of excessive blood loss is further highlighted in cases of simultaneous bilateral total knee replacement where blood loss is usually twice that of a unilateral knee replacement and the number of allogenic blood units transfused can be as high as three to four per person $[11,12]$. Risks associated with allogenic blood transfusion are numerous and well documented. Of these the most important are blood borne infections, immunological reactions and cost incurred in producing a unit of red cells [13-15].

Tranexamic acid is an antifibrinolytic agent, which effectively blocks this fibrinolytic activity, thus causing a 
marked reduction in post-operative bleeding. It works by blocking the lysine binding sites of plasminogen and prevents the degradation of fibrin. It has been previously used quite successfully in urological, gynecological and thoracic surgical procedures in order to reduce postoperative blood loss [16-19]. The use of tranexamic acid in orthopedic surgery has also shown promising results. It radically reduced both blood loss and the amount of allogenic transfusions needed postoperatively [9,20-22]. Considering the high risks associated with the use of allogenic blood, we think that this drug can be very beneficial to patients undergoing both unilateral and simultaneous bilateral total knee replacements.

- The aim of this study was to determine: if the use of tranexamic acid reduces perioperative blood loss and need for allogenic blood transfusion in patients undergoing total knee replacement

- Any untoward effects with the use of this drug in our population

\section{Materials and methods}

All patients having undergone total knee replacement at our hospital between November 2005 to November 2008 were included in the study sample.

A total of 99 patients with 128 knee joints were included in the study. Patients from Group I received one gram of IV tranexamic acid before inflation of the tourniquet and $1 \mathrm{~g}$ after deflation of tourniquet. Sixtysix patients $(66.4 \%)$ underwent unilateral and 23 patients (24.6\%) had bilateral procedures.

All patients with no known bleeding disorders who under-went TKR were included in our study. All patients were given routine DVT prophylaxis with Injection Enoxaparin $40 \mathrm{mg}$ subcutaneous once a day. Anaesthesia was standardized and all patients received epidural anaesthesia according to standard practice. Patients receiving chronic anticoagulants were excluded from the study. Haemoglobin was measured preoperatively, one hour postoperatively and at 72 hours postoperatively. The same surgical team performed all procedures and the same implant (IB-II - Zimmer, Warsaw, IN) was used in all patients. Patellar replacement was performed in all cases and all components were cemented.The established practice of transfusion in our unit is that patients are transfused if:

1. Postoperative $\mathrm{Hb}$ is $<7 \mathrm{mg} / \mathrm{dl}$ in patients with no coronary heart disease, or $<9 \mathrm{mg} / \mathrm{dl}$ in patients who have coronary heart disease

2. Physiological signs of inadequate oxygenation such as hemodynamic instability or symptoms of myocardial ischemia occur

3. Drainage of more than 1 liter of blood in the first 24 hours
47 patients with $32(68 \%)$ undergoing a unilateral and 15 (32\%) undergoing simultaneous bilateral total knee replacement had received tranexamic acid and these were labelled as Group-I. Data form Group-I was collected retrospectively by chart review and then compared with that of Group-II which was a historical control group. Group-II underwent the same procedure of either a unilateral or simultaneous bilateral total knee replacements, but did not receive tranexamic acid and also did not undergo any other procedure to reduce post-operative bleeding. Patients in both groups were age and disease-matched. There were 52 patients in Group-II with 38 (76\%) undergoing a unilateral and 14 (24\%) undergoing a simultaneous bilateral knee replacement procedure.

Student t-test was used to compare the means via SPSS 13.

\section{Results}

Mean age of our study population was 59 years [Figure 1] $70 \%$ were females and $30 \%$ were male patients. Indication for surgery in $71 \%$ of the patients was osteoarthritis while in $29 \%$ of the patients it was rheumatoid arthritis.

The mean drop in the post-operative haemoglobin concentration unilateral surgery was $1.49 \mathrm{gm} / \mathrm{dl}$ in group Ii and $1.79 \mathrm{gm} / \mathrm{dl}$ in group II, a difference of $17 \%$. for bilateral surgery, the drop was $1.94 \mathrm{gm} / \mathrm{dl}$ and $2.21 \mathrm{gm} / \mathrm{dl}$ respectively, a difference of $12 \%$. mean postoperative blood drainage in unilateral surgery was $826 \mathrm{ml}$ and 1828 $\mathrm{ml}$ respectively, a difference of $55 \%$, while in bilateral surgery it was $1288 \mathrm{ml}$ and $2695 \mathrm{ml}$ respectively, a difference of $52 \%$. Mean drop in the post-operative haemoglobin concentration and mean post-operative drainage of both Group-I and Group-II is given in Table 1. Thirty-nine (75\%) out of 52 patients in this Group-II required transfusion. Thirty-two $(61.53 \%)$ patients required one or two

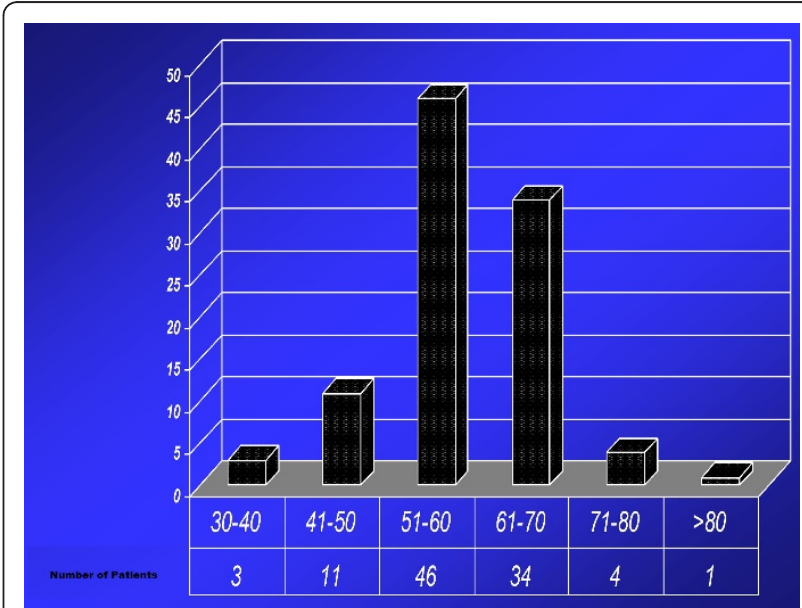

Figure 1 Age groups 
Table 1 Summary of results

\begin{tabular}{|c|c|c|c|c|c|c|c|}
\hline & \multicolumn{2}{|c|}{$\begin{array}{l}\text { Mean Post-Operative } \\
\text { Drainage }\end{array}$} & \multicolumn{2}{|c|}{$\begin{array}{l}\text { Mean Drop in } \\
\text { Post-Operative HB }\end{array}$} & \multicolumn{2}{|c|}{$\begin{array}{l}\text { Mean number of Packed } \\
\text { Cells Transfused }\end{array}$} & \multirow[t]{2}{*}{$\begin{array}{l}\text { Number of Patients } \\
\text { requiring Transfusion }\end{array}$} \\
\hline & Unilateral & Bilateral & Unilateral & Bilateral & Unilateral & Bilateral & \\
\hline Group-I (N = 47) & $826 \mathrm{ml}$ & $1288 \mathrm{ml}$ & $1.49 \mathrm{~g} / \mathrm{dl}$ & $1.94 \mathrm{~g} / \mathrm{dl}$ & 0.12 & 0.9 & 6 \\
\hline Group-II (N = 52) & $1828 \mathrm{ml}$ & $2695 \mathrm{ml}$ & $1.79 \mathrm{~g} / \mathrm{dl}$ & $2.21 \mathrm{~g} / \mathrm{dl}$ & 1.24 & 2.6 & 35 \\
\hline$p$ value & $<0.001$ & $<0.001$ & 0.0005 & $<0.0005$ & 0.005 & 0.043 & \\
\hline
\end{tabular}

units of packed red cells and seven (13.46\%) patients required more than two units of transfusion in this group. In comparison, only $6(12.76 \%)$ out of the 47 patients in Group-I required blood transfusion and remaining 22 (88.24\%) had not required any transfusion. This difference between the two groups in the number of units of blood transfused is statistically significant ( $\mathrm{p}$-value $<0.001$ ). A statistically significant ( $\mathrm{p}$-value $<0.01$ ) difference in transfusion requirement for patients with Osteoarthritis and Rheumatoid Arthritis was also noted [Figure 2]. No untoward side effect of tranexamic acid was noted in our patients.

\section{Discussion}

Knowing all the risks and morbidity associated with allogenic blood transfusion, a surgeon always looks for ways and means whereby allogenic blood transfusion can be avoided in surgical patients. The most noticeable, and extensively explored options available are preoperative blood donation (PAD), acute normovolemic hemodilution (ANH), perioperative red cell salvage (PCS) and certain anaesthetic techniques (deliberate hypotension, normothermia) [23]. Certain pharmacological interventions that have been used with success are Recombinant Human Erythropoietin, tranexamic acid and Aprotinin. However, none of these agents are without complications [table 2] and the most important factors to consider in the developing world are the availability and cost effectiveness of these strategies.

Tranexamic acid, by way of its anti-fibrinolytic action, prevents clot breakdown and a consequent re-bleed.

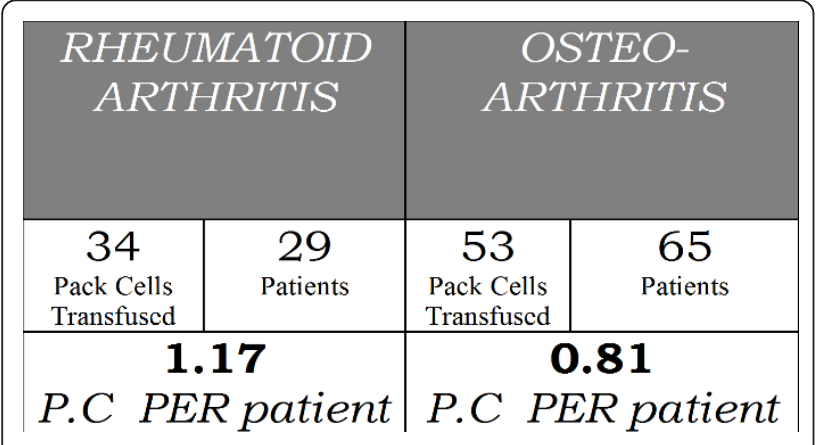

Figure 2 Comparison of transfusion requirement in Osteoarthritis \& Rheumatoid arthritis.
Our results demonstrate significant reduction in blood loss with the use of tranexamic acid. Other studies have also had similar results [20,22]. A meta analysis which looked at double blinded randomized controlled trial also found that tranexamic acid was useful in reducing blood loss in major orthopedic procedures [24].

No adverse effects were seen in our population with the use of tranexamic acid. Although side effects have been reported in other large scale studies but none of them were serious enough to warrant disuse of the drug [25,26].

In South Asia, apart from poverty, low literacy, social factors that result in the inability of women to negotiate safe sex, intravenous drug use and unsafe transfusion is regarded as one of the most important factors that

Table 2 Different methods of blood conservation and their complications

\begin{tabular}{ll}
\hline Alternatives used to avoid allogenic blood transfusions and their \\
disadvantages
\end{tabular}


influence transmission of infection [27,28]. High frequency of viremia due to transfusion-transmitted virus was observed in most of the study populations from third world countries, with values ranging from 16 percent in Pakistan to 83 percent in Gambia [29]

A large scale study [30] in Pakistan has shown that the screening coverage on the average has been $77.42 \%$ for HIV and $86.84 \%$ for HBV. The prevalence of HIV is $0.001 \%$ and of HBV is $2.259 \%$ [30]. The probability of receiving an infective unit $\mathrm{P}(\mathrm{R})$ per 10000 donations is 0.023 for HIV and 29.72 for HBV. The probability of transmitting infection $\mathrm{P}$ (I) per 10000 donations is 0.021 for HIV and 26.75 for HBV. The spreading index for both viral infections combined is 26.75 per 10000 donations. Although $80 \%$ of joint replacement procedures take place in the United States and Europe, South Asia is not far behind with an estimated 40-50 thousand joint replacement procedures already done yearly in India alone [31]. Number of knees replaced annually in Pakistan is estimated to be 1500-2000 [32].

The cost of one unit of red cells is estimated 120 pounds [14] in Britain while it costs 19.20 British Pounds in Pakistan [33]. The regimen of tranexamic acid that was administered in our study population costs 3.75 Pounds. These figures reflect that if one is able to decrease the requirement of blood by even one unit per patient the cumulative effect will be a decrease of burden on the health care system. Countries where individuals pay for their own health care and there is no third party plan (health insurance companies) involved can benefit from adopting such cost effective measures.

Although we conducted a retrospective analysis of a relatively small number patients and the possibility of the results being affected by recall bias due to historical controls cannot be ruled out it does provide the basis for conducting larger scale prospective randomized studies in order to determine the efficacy of tranxemic acid in reducing perioperative blood loss.

We believe that the use of tranexamic acid in TKR surgery is a low cost option in reducing the requirement of allogenic blood transfusion.

\footnotetext{
Author details

${ }^{1}$ Aga Khan University Medical College, Karachi-74800, Pakistan. ${ }^{2}$ Associate Professor Department of Surgery (Orthopedics) Aga Khan University Hospital, Karachi-74800, Pakistan. ${ }^{3}$ Assistant Professor Department of Surgery (Orthopedics) Aga Khan University Hospital, Karachi-74800, Pakistan. ${ }^{4}$ Professor Department of Surgery (Orthopedics) Aga Khan University Hospital, Karachi-74800, Pakistan.
}

\section{Authors' contributions}

YJS did the overall supervision and participated in the conception of the idea, preparation of the questionnaire and protocol, collection of data and writing the manuscript. MU was involved in the overall supervision, preparation of the questionnaire and collection and analysis of data. TA was involved in the study design, analysis and was involved in critically reviewing the manuscript. FA and MUC participated in the designed the study and participated in the preparation of the protocol and data collection. MU participated in overall supervision and critically reviewed the manuscript. All authors read and approved the final manuscript.

\section{Competing interests}

The authors declare that they have no competing interests.

Received: 13 October 2010 Accepted: 21 May 2011

Published: 21 May 2011

References

1. Cushner FD, F R: Blood loss in total knee arthroplasty. Clin Orth 1991, 269:98-101.

2. Fragen RJ, S S, Wixson R, et al: Effect of Ketorolac tromethamine on bleeding and requirements for analgesia after total knee arthroplasty. $J$ Bone Joint Surg(Am) 1995, 77:998-1002.

3. Bukart $\mathrm{BC}, \mathrm{B} \mathrm{R}$, Rorabeck $\mathrm{CH}$, et al: The efficacy of tourniquet release in blood conservation after total knee replacement. Clin Orth 1994, 299:147-52.

4. Karnezis TA, S S, Wixson RL, Reilly P: The hemostatic effects of desmopressin on patients who had total joint arthroplasty. J Bone Joint Surg(Am) 1994, 76:1545-50.

5. Mylod AG, F M, Muser DE, Parsons JR: Perioperative blood loss associated with total knee arthroplasty. J Bone Joint Surg(Am) 1990, 72:1010-2.

6. Fauno $P, S \mathrm{O}$, Rehnberg V, et al: Prophylaxis for the preventiopn of venous thromboembolism after total knee arthroplasty. J Bone Joint Surg (Am) 1994, 76:1814-8.

7. Goodnough LT, V D, Marcus RE: The relationship between hematocrit, blood lost and blood transfused in total knee replacement. Am J Knee Surg 1995, 8:83-7.

8. Klenerman L, M I, Chakrabarti R, et al: Changes in the hemostatic system after application of a tourniquet. Lancet 1977, 1:970-2

9. Benoni G, C A, Petersson C, Fredin H: Does Tranexamic Acid reduces blood loss after total knee arthroplasty? Am J Knee Surg 1995, 8:88-92.

10. Petaja J, M P, Myllyla G, Vahtera E: Fibrinolysis after application of a pnematic tourniquet. Acta Chir Scand 1987, 153:647-51.

11. Martin JW, W L, Milliano MT, Reedy ME: Post operative blood Retrieval and transfusion in cementless total knee arthroplasty. J Arthroplasty 1992, 7:205-10.

12. Lane GJ, H W, Shah S, Rothman RH, Booth RE Jr, Engh K, Smith P. Simultaneous bilateral versus unilateral total knee replacement arthroplasty. Outcomes Analysis. Clin Orthop 1997, 345:106-12.

13. Nozoe Tadahiro, M M, Saeki Hiroshi, Ohga Takefumi, Keizo Sugimachi: Significance of allogenic blood transfusion on decreased survival in patients with esophageal carcinoma. Cancer 2001, 92(7):1913-18.

14. Brian McClelland MC: Appropriateness and safety of blood transfusion. BMJ 2005, 330:104-105

15. Spanh DR, C M: Eliminating blood transfusions. New aspects and perspectives. Anesthesiology 2000, 93:242-55.

16. $\mathrm{PO}, \mathrm{H}:$ Antifibrinolytic therapy with Cyklopropan in connection with prostatectomy: a double blind study. Scand J Urol Nephrol 1969, 3:177-82.

17. Dunn CJ, G K: Tranexamic Acid: a review of its use in surgery and other indications. Drugs 1999, 57:1005-32.

18. Bekasssy Z, A B: Treatment with fibrinolytic inhibitor tranexamic acid: risk for thrombosis? Acta Obstet Gynecol Scand 1990, 69:353-4.

19. Kataros D, P M, Snow NJ, Woodland DD, Van Bergan : Tranexamic Acid reduces postbypass blood loss: a double blinded, prospective, randomised study of 210 patients. Ann Thorac Surg 1996, 61:1131-5.

20. Hiippala ST, S L, Wennerstrand MI, Arvela JV, Niemel a HM, M antyl a SK, Kuisma RP, Ylinen JE: Tranexamic Acid radically reduces blood loss and transfusions associated with total knee arthroplasty. Anesth Analg 1997, 84:839-44

21. Hiippala S, S L, Wennerstrand M: Tranexamic Acid (Cyklopropan) reduces perioperative blood loss associated with total knee arthroplasty. $\mathrm{Br} J$ Anesth 1995, 74:534-7.

22. Benoni G, G H: Fibrinolytic inhibition with tranexamic acid reduces blood loss and blood transfusion after knee arthroplasty: A prospective, randomized, double blind study of 86 patients. J Bone Joint Surg Br 1996, 78:434-440.

23. Rosenblatt MA: Strategies for minimizing the use of allogeneic blood during orthopedic surgery. Mt Sinai J Med 2002, 69(1-2):83-7. 
24. Zufferey Paul, F M, Laporte Silvy, Decousus Herve', Mismetti Patrick, Auboyer Christian, Charles Marc Samama, Molliex Serge: Do Antifibrinolytics Reduce Allogeneic Blood Transfusion in Orthopedic Surgery? Anesthesiology 2006, 105:1034-46.

25. Ip, P P, et al: Tranexamic acid-associated necrosis and intralesional thrombosis of uterine leiomyomas: a clinicopathologic study of 147 cases emphasizing the importance of drug-induced necrosis and early infarcts in leiomyomas. Am J Surg Pathol 2007, 31(8):1215-24.

26. Sethna NF, et al: Tranexamic acid reduces intraoperative blood loss in pediatric patients undergoing scoliosis surgery. Anesthesiology 2005, 102(4):727-32.

27. Chrishantha Abeysenaa HJdS: HIV in South Asia. Medicine 2005, 33(6):42-43.

28. Ali S, T W, Khan A: Viral hepatitis in children. AFIP Rawalpindi, Pakistan; 1998.

29. Linda E, Prescott PS: Global Distribution of Transfusion-Transmitted Virus. NEJM 1998, 339(11):776-777.

30. Mahfooz ur Rahman AGN, Lodhi Y: Transfusion transmitted HIV \&amp; HBV infections in Punjab, Pakista. Pakistan Journal of Medical Sciences 2002, 18(1):18-25.

31. Mukherjee Rupali T: India to be largest market for knee, hip replacements. in The Times of India. 2007.

32. Sons Fa: Number of total knee implants supplied to Pakitan. Karachi; 2007.

33. Aga Khan University Hospital Karachi, Pakistan. Price list. [http://www. aku.edu/AKUH/Patient_Visitor/page6.shtml].

34. Gandini $\mathrm{G}$, et al: Preoperative autologous blood donation by 1073 elderly patients undergoing elective surgery: a safe and effective practice. Transfusion 1999, 39(2):174-8.

35. Trouern-Trend J, et al: A case-controlled multicenter study of vasovagal reactions in blood donors: influence of sex, age, donation status, weight, blood pressure, and pulse. Transfusion 1999, 39(3):316-20.

36. Forgie MA, et al: Preoperative autologous donation decreases allogeneic transfusion but increases exposure to all red blood cell transfusion: results of a meta-analysis. International Study of Perioperative Transfusion (ISPOT) Investigators. Arch Intern Med 1998, 158(6):610-6.

37. Sculco TP, Gallina J: Blood management experience: relationship between autologous blood donation and transfusion in orthopedic surgery. Orthopedics 1999, 22(Suppl 1):s129-34.

38. Etchason J, et al: The cost effectiveness of preoperative autologous blood donations. N Engl J Med 1995, 332(11):719-24.

39. Bryson GL, Laupacis A, Wells GA: Does acute normovolemic hemodilution reduce perioperative allogeneic transfusion? A meta-analysis. The International Study of Perioperative Transfusion. Anesth Analg 1998, 86(1):9-15.

40. Umlas J, et al: Red cell loss following orthopedic surgery: the case against postoperative blood salvage. Transfusion 1994, 34(5):402-6.

41. Lee AG: Ischemic optic neuropathy following lumbar spine surgery. Case report. J Neurosurg 1995, 83(2):348-9.

42. Stevens WR, et al: Ophthalmic complications after spinal surgery. Spine (Phila Pa 1976) 1997, 22(12):1319-24.

43. James ML, Keifer JC: Posterior optic nerve ischemic neuropathy in the setting of phenoxybenzamine therapy after uneventful spinal fusion. $J$ Neurosurg Anesthesiol 2011, 23(2):169-70.

44. Coyle $\mathrm{D}$, et al: Economic analysis of erythropoietin use in orthopaedic surgery. Transfus Med 1999, 9(1):21-30.

45. Kasper SM, et al: A retrospective study of the effects of small-dose aprotinin on blood loss and transfusion needs during total hip arthroplasty. Eur J Anaesthesiol 1998, 15(6):669-75.

46. Royston D, van Haaften N, De Vooght P: Aprotinin; friend or foe? A review of recent medical literature. Eur J Anaesthesiol 2007, 24(1):6-14.

doi:10.1186/1749-799X-6-22

Cite this article as: Sepah et al: Use of Tranexamic acid is a cost effective method in preventing blood loss during and after total knee replacement. Journal of Orthopaedic Surgery and Research 2011 6:22.

\section{Submit your next manuscript to BioMed Central and take full advantage of:}

- Convenient online submission

- Thorough peer review

- No space constraints or color figure charges

- Immediate publication on acceptance

- Inclusion in PubMed, CAS, Scopus and Google Scholar

- Research which is freely available for redistribution

Submit your manuscript at www.biomedcentral.com/submit 